\title{
MONITORING THE CELL WALL CHARACTERISTICS OF DEGRADED BEECH WOOD BY WHITE-ROT FUNGI: ANATOMICAL, CHEMICAL, AND PHOTOCHEMICAL STUDY
}

\author{
Ehsan Bari ${ }^{1,}$, Behbood Mohebby ${ }^{2}$, Hamid Reza Naji ${ }^{3}$, Reza Oladi', Nural Yilgor ${ }^{5}$, \\ Nouredin Nazarnezhad ${ }^{6}$, Katie M. Ohno ${ }^{7}$, Darrel D. Nicholas ${ }^{8}$
}

\begin{abstract}
Meticulous chemical analysis of decaying xylem and linking it to corresponding anatomical modification at the cellular level can improve our understanding of the decay process. The aim of this study was to monitor the histological, chemical, photochemical, and progression of wood degradation by two white-rot fungi at different intervals. Oriental beech wood (Fagus orientalis) blocks were exposed to Pleurotus ostreatus and Trametes versicolor to investigate the degradation capabilities of these two fungi. Light microscopy was used to study the decay patterns in wood. Decayed wood samples were also analyzed to determine lignin, cellulose and sugar contents and also evaluated at two week intervals by FT-IR spectroscopy to study chemical alterations. According to chemical analyses lignin is the most degraded polymer followed by cellulose and hemicelluloses for both white rot fungi. However, both test fungi tended to consume lignin more than cellulose. FT-IR spectra changes for lignin and carbohydrates in beech wood supported chemical alteration and indicated that both fungi decay wood in a simultaneous pattern.
\end{abstract}

Keywords: Carbohydrate degradation, cell wall decomposition, FT-IR, Oriental beech wood, simultaneous white-rot, wood chemistry, wood decay.

\section{INTRODUCTION}

The structural materials of woody plants consist of three natural polymers: lignin, cellulose, and hemicelluloses. These renewable resources are produced naturally and can be degraded by various biological agents (Hatakka and Hammel 2010, Kubicek 2013). Cellulose, a homopolysaccharide and major components of woody plants, is composed of $\beta$-D-glucopyranoside units and includes crystalline, sub-crystalline, and even amorphous areas (Ding and Himmel 2008). The average degree

\footnotetext{
${ }^{1}$ Department of Wood Science and Engineering, Technical Faculty of No. 2, Mazandaran Branch, Technical and Vocational University (TVU), Sari, Iran. bari_lenzites@yahoo.com

${ }^{2}$ Department of Wood and Paper Sciences, Faculty of Natural Resources, Tarbiat Modares University, Noor, Iran. mohebbyb@ modares.ac.ir

${ }^{3}$ Department of Forest Science, University of Ilam, Ilam, Iran. hrn_16hrn@ilam.ac.ir

${ }^{4}$ Department of Wood Science and Technology, Faculty of Natural Resources, University of Tehran

Karaj, Iran.oladi@ut.ac.ir

${ }^{5}$ Department of Forest Products Chemistry and Technology Division, Forest Industry Engineering, Forestry Faculty, Istanbul University, Istanbul, Turkey. yilgorn@istanbul.edu.tr

${ }^{6}$ Department of Wood and Paper Science, Sari Agriculture and Natural Resources University, Sari, Iran.n.nazarnezhad@sanru. ac.ir

${ }^{7}$ USDA Forest Service, Forest Products Laboratory, One Gifford Pinchot Drive, Madison, Wisconsin, U.S.A. kohno@fs.fed.us

${ }^{8}$ Department of Sustainable Bioproducts, Mississippi State University, Mississippi State, USA. ddn1@msstate.edu

"Corresponding author: bari_lenzites@yahoo.com
}

Received: 07.01.2017 Accepted: 07.10.2017 
of polymerization (DP) of cellulose is between 1000-3000. In contrast, hemicelluloses are mainly heteropolymers consisting of short and branched xylose, galactose, mannose and arabinose units (Sjöström 1993). It has been shown that hemicelluloses are linked to lignin units by way of cinnamate acid ester linkages and through interchain hydrogen bonding as well as covalent bonds with cellulose (Koshijima and Watanabe 2003). The tertiary and complex polymer in plant tissue is lignin, and contains amorphous and three-dimensional aromatic components which are formed via the oxidative coupling of p-hydroxycinnamyl alcohol monomers, dimethoxylated (syringyl, S), monomethoxylated (guaiacyl, G) and non-methoxylated ( $p$-hydroxyphenyl, H) phenylpropanoid units. Lignin is highly polydisperse in nature and the determination of its molecular weight is very difficult (Argyropoulos and Menachem 1997).

Carbon cycling in forest ecosystems is mainly carried out via wood decay saprophytes (Rayner and Boddy 1988, Aghajani et al. 2017). During the decay process, carbohydrates are broken down into simple sugars by fungal enzymes (Schmidt 2006). Specific basidiomycetes, or white-rot decay fungi, play a critical role in wood degradation. These fungi are unique organisms because they can deconstruct natural polymers like lignin (Koshijima and Watanabe 2003, Hatakka and Hammel 2010). In addition, other fungi in the class Ascomycetes, specifically members of the Xylariaceae family, can produce type II soft-rot, or pseudo-white-rot, of lignocellulose material (Blanchette 1995, Liers et al. 2006).

Wood decaying fungi use enzymatic and non-enzymatic mechanisms to degrade the wood cell wall layers (Schmidt 2006). These fungi are able to enzymatically degrade the wood cell walls into components that can easily be digested (Eriksson et al. 1990, Kubicek 2013). Therefore, it is apparent that these fungi have a complete set of genes for wood cell wall decomposition of woody plants (Stokland et al. 2012).

Determining the destructive behaviors of white-rot fungi on woody material has been studied by various methods (Cowling 1961, Wilcox 1973, Mohebby 2005, Hervé et al. 2014, Schmidt et al. 2016). Understanding white-rot degradation of wood is of great importance for industry (Fackler et al. 2011) since the products can be used in line of biotechnology goals (Kirk et al. 1993, Schubert et al. 2011). It is especially informative to detect and clarify simultaneous white-rot processes from selective white-rot processes. This separation is usually based on microscopic features of decayed wood (Liese 1970). From an anatomical point of view, in selective delignification, secondary cell wall with modified cellulose and part of the hemicelluloses remains; while in simultaneous rot, holocelluloses and lignin are removed at approximately the same rates in the vicinity of the hyphae (Schwarze et al. 2004). Directly monitoring chemical loss in xylem attacked by white-rot fungi and linking it to anatomical modification in wood cells can improve our knowledge about decay progression.

The white-rot fungi Pleurotus ostreatus and Trametes versicolor are well-know predator and terminator agents (Bari et al. 2016) which are used in different laboratory experiments such as bioresistance of wood and wood products (Schmidt 2006) as well as bioremediation of wood treated by different chemical materials (Kartal et al. 2015). It has been reported that wood decay by the whiterot fungus Pleurotus mainly ligninolytic (Martinez et al. 2001, Martinez et al. 2005, Baldrian 2008, Kubicek 2013), while the results of recent studies show both cellulolytic and lignolytic reactions. (Bari et al. 2015a, Bari et al. 2015b, Bari et al. 2015c, Bari et al. 2015d, Karim et al. 2016). On the other hand, recent studies have reported that the white rot fungus $P$. ostreatus also has a capability of producing soft rot decay in oak wood under natural condition (Bari et al. 2017). Nevertheless, it has been shown that the strategies of fungi can also be altered in accordance with ambient environmental conditions (Adaskaveg et al. 1995, Schwarze et al. 2004, Woodward and Boddy 2008). Moreover, a previous study on the changes in destructive behavior of P. ostreatus by (Martinez et al. 2001, Martinez et al. 2005) suggested that selective degradation occurred with this fungus. Thus, understanding fungal destructive behavior requires a detailed monitoring and tracing by time elapsed periods. In a similar work (Hale and Eaton 1985a, Hale and Eaton 1985b) distinguished that called 'time-lapse photography" how the soft rot fungi can degrade the wood cell wall. Hence, the objective of the current study was to provide more detailed information on chemical changes that occurred in Oriental beech wood (Fagus orientalis) which has been attacked by the white rot fungi P. ostreatus and T. versicolor at different stages of the decay. 


\section{MATERIALS AND METHODS}

\section{Wood sample preparation}

Sample disks were cut from Oriental beech trees (Fagus orientalis Lipsky.) at breast height. Sample blocks as $50(1) \times 20(\mathrm{t}) \times 15(\mathrm{r}) \mathrm{mm}$ were then prepared from these disks to determine mass loss according to EN113 (1997). Dry mass and initial moisture contents of the blocks were determined prior to autoclaving (at $121^{\circ} \mathrm{C}$ for $20 \mathrm{~min}$ ). Following this, the blocks were placed in the decay test containers and inoculated with each test fungus.

\section{Fungal identification and incubation}

The fruiting bodies of $P$. ostreatus and T. versicolor were recovered from living beech trees $(F$. orientalis) at Alamdardeh forest (located in Sari, Iran). For isolation and identification of the fungi, small wood blocks were surface-sterilized with $95 \%$ ethanol for $10-15 \mathrm{sec}$ followed by $1 \%$ sodium hypochlorite for 45-50 sec. Thereafter, the wood pieces were inoculated on Potato Dextrose Agar (PDA) medium. Cultures were incubated at $25^{\circ} \mathrm{C}$ for complete growth. A pure culture was obtained after successive transfer on MEA medium by hyphal tip purification, and preserved at $4^{\circ} \mathrm{C}$. Molecular identification was done based on Polymerase Chain Reaction (PCR) in accordance with (Schmidt et al. 2012, Bari 2014). The fungi were identified by DNA extraction and sequencing of the internal transcribed spacer region (ITS). The forward primer, ITS5, and reverse primer, ITS4, were used. PCR products were sent to Takapozist (Bioneer- Korea) for sequencing. Identification was done by sequence comparison with sequences deposited in the DNA databases using the NCBI's BLAST tool.

For mass loss determination, Kolle-flasks containing Malt-extract-agar (MEA) $(4,8 \%)$ were prepared and autoclaved at $121^{\circ} \mathrm{C}$ for 20 min according to EN 113 (1997). Prepared malt extract was inoculated with actively growing fungal cultures and incubated until the surface of the medium was covered with mycelial growth. Autoclaved wood blocks were placed directly on the mycelia and incubated at $25^{\circ} \mathrm{C}$ and $65 \%$ relative humidity (RH) for 120 days. Ten of these blocks were harvested every 15 days for the duration of the experiment for mass loss determination. The remaining samples were used for microscopy and FT-IR spectroscopy.

\section{Chemical analysis}

Decayed and undecayed wood specimens from each sampling time point were ground to pass the powder through sieve (40-mesh) prior to analysis. Cellulose and lignin analysis was performed using the T-17 wd-97 (TAPPI 1997) and T-222 om-98 (TAPPI 1998) specifications, respectively. A modified T-249 cm-85 (TAPPI 1992) method for carbohydrate analysis (Davis 1998) was used to determine total hemicellulose content. Average cellulose, lignin, and hemicellulose loss of decayed wood was calculated as a percent of the corresponding values for the unexposed samples.

\section{Light and SEM microscopic imaging}

Samples exposed to the fungi for 120 days were cut into small cubes $(5 \times 5 \times 5 \mathrm{~mm})$ and then sectioned with a sledge microtome $(\sim 10 \mu \mathrm{m})$. Since the moisture content of specimens was high and the tissue was soft, sectioning was carried out right after incubation, without any pretreatments. To distinguish the cell wall and hyphae, sections were double-stained with safranin $\mathrm{O}(0,5 \%)$ and Astrablue $(0,3 \%)$ dissolved in distilled water followed by conventional microscopy including dehydration and mounting on microscopic slides (Gartner and Schweingruber 2013, Bari et al. 2015c). The prepared slides were studied by BEL epifluorescence microscopy under bright field and ultraviolet light (330-400nm). Under bright field light, lignified cell walls appear red while hyphal walls and delignified xylem cells get blue color. UV fluorescence microscope, on the other hand, was used to qualitatively trace lignified versus delignified cells of xylem. 
For scanning electron microscopy, the mini-blocks of decayed wood samples $(5 \times 5 \times 5 \mathrm{~mm})$ were clean cut using a razor blade and then chemically fixed according to Mohebby (2003). Sections were then mounted on SEM stubs, and sputter coated to a thickness of $30 \mathrm{~nm}$ with gold. A SEM microscope (VEGA\TESCAN-LMU) was used for observation.

\section{FT-IR spectroscopy}

Dried wood samples were milled and sieved through a 40 mesh screen. The IR-spectra were obtained directly from wood powder using ATR technique by a Shimadzu 8400s FT-IR Spectrometer equipped with DLATGS detector. All samples were examined at a spectral resolution of $4 \mathrm{~cm}^{-1}$ with 30 scans for each sample as well as the background. The background spectra were collected using an empty collector. A rubber band baseline correction method was also applied for all spectra. The $\mathrm{CO}_{2}$ band was also removed from the spectra to make a suitable baseline correction (Mohebby 2005).

\section{RESULTS AND DISCUSSION}

\section{Mass loss}

The average mass loss of the wood samples at different periods of exposure to the white rot fungi, $P$. ostreatus and $T$. versicolor, are presented in Table 1. The data shows that both fungi attacked beech wood with similar decay capabilities resulting in an almost identical amount of mass loss. Both fungi decreased the wood mass about $15-18 \%$ at 30 days exposure and $26 \%$ after 120 days exposure. Both fungi exhibited similar capabilities to severely attack the wood within the first month (Table 1). Similar results were also previously reported by authors (Bravery 1978 and Bari et al. 2015d). Minor fluctuations in mass loss among blocks were also similar for both fungi.

Table 1. Average of percent mass losses in decayed Oriental beech wood samples by white-rot fungi ${ }^{\mathrm{a}}$.

\begin{tabular}{|c|c|c|c|c|c|c|c|c|}
\hline \multirow{2}{*}{ Fungus } & \multicolumn{8}{|c|}{ Exposure time (days) } \\
\cline { 2 - 9 } & 15 & 30 & 45 & 60 & 75 & 90 & 105 & 120 \\
\hline & 7,03 & 15,65 & 14,15 & 18,88 & 21,57 & 21,18 & 24,10 & 26,66 \\
& \pm & \pm & \pm & \pm & \pm & \pm & \pm & \pm \\
P. ostreatus & 0,51 & 0,44 & 0,02 & 0,09 & 0,30 & 0,02 & 0,10 & 2,70 \\
\hline & 8,50 & 18,21 & 17,21 & 20,74 & 23,73 & 21,46 & 25,32 & 26,43 \\
& \pm & \pm & \pm & \pm & \pm & \pm & \pm & \pm \\
T. versicolor & 0,63 & 0,64 & 0,64 & 0,63 & 0,12 & 0,50 & 0,67 & 1,20 \\
\hline
\end{tabular}

\pm values represent standard deviations of the means.

${ }^{\text {a }}$ Data in table reported from Bari et al. 2016.

\section{Cell wall chemistry decomposition}

The average cellulose, lignin, and total carbohydrate contents of unexposed beech wood were $39,6 \% ; 22,2 \%$ and $67,6 \%$ of the dry wood weight, respectively. As shown in Table 2 , both fungi were able to attack cellulose. Hemicellulose components were also attacked by both test fungi. The amount of cellulose and lignin remaining after fungal attack indicates similar capabilities of two fungi to degrade wood. Because these two white rot fungi are Basidiomycetes, they should degrade carbohydrates and lignin to a similar extent (Eriksson et al. 1990). Cellulose is composed of two parts, crystalline and 
amorphous (Sjöström 1993, Kubicek 2013). The amorphous region is much more susceptible than crystalline region for initial fungal metabolism (Eaton and Hale 1993). Hence, a high rate of cellulose deconstruction at initial attack by the fungus would be normal. One of the major components in plant cell walls is the side by side chains of multiple hydroxyl groups in glucose (Klemm et al. 2004, O'Sullivan 1997). To degrade the cellulose chains, fungi need specific enzymes such as endo- and exocellulases and $\beta$-glucosidase and most of the white-rot fungi are able to produce these enzymes (Eriksson et al. 1990, Eaton and Hal 1993, Kubicek 2013). It seems that nonselective white-rot fungi have these enzymatic systems. Since white-rot fungi use a hydrolysis system for the decomposition of cellulose chains (Kubicek 2013), they can cleave cellulosic chains by producing endoglucanase enzymes that can hydrolyze the $\beta$-1,4-glycosidic bonds which breaks down crystalline cellulose to cellobiose (Eriksson et al. 1990, Kubicek 2013).

Table 2. Average of percent wood cell wall polymers losses in decayed Oriental beech wood samples by white-rot fungi.

\begin{tabular}{|c|c|c|c|c|c|c|c|c|c|}
\hline \multirow{2}{*}{ Fungus } & \multirow{2}{*}{$\begin{array}{l}\text { Wood cell } \\
\text { wall } \\
\text { polymers }\end{array}$} & \multicolumn{8}{|c|}{ Exposure time (days) } \\
\hline & & 15 & 30 & 45 & 60 & 75 & 90 & 105 & 120 \\
\hline \multirow{47}{*}{$\begin{array}{l}\text { P. } \\
\text { ostreatus }\end{array}$} & \multirow[t]{3}{*}{ Cellulose } & 7,05 & 10,22 & 7,82 & 14,66 & 18,17 & 16,97 & 21,29 & 19,94 \\
\hline & & $=$ & $=$ & \pm & $=$ & $=$ & $=$ & \pm & $=$ \\
\hline & & 0.50 & 2.67 & 0.47 & 0.82 & 0.46 & 0,30 & 0,08 & 2.85 \\
\hline & \multirow[t]{2}{*}{ Lignin } & 17,53 & 29,52 & 26,22 & 42,71 & 46,43 & 43,31 & 51,71 & 56,51 \\
\hline & & \pm & $=$ & $=$ & \pm & \pm & \pm & \pm & $=$ \\
\hline & \multirow{3}{*}{ Arabinan } & $\begin{array}{l}., 04 \\
4,81\end{array}$ & $\begin{array}{c}3,30 \\
-2,41\end{array}$ & $\begin{array}{l}0.02 \\
8.82\end{array}$ & $\begin{array}{l}1.72 \\
0.80\end{array}$ & $\begin{array}{c}0,45 \\
-3,21\end{array}$ & $\begin{array}{l}0.50 \\
8.82\end{array}$ & $\begin{array}{c}0,65 \\
-5,61\end{array}$ & $\begin{array}{c}0,38 \\
-0,80\end{array}$ \\
\hline & & $=$ & $=$ & \pm & $=$ & \pm & $=$ & \pm & $=$ \\
\hline & & 0,00 & 0.02 & 0,01 & 0.00 & 0,00 & 0.02 & 0.02 & 0.01 \\
\hline & \multirow[t]{3}{*}{ Galactan } & 20,03 & $-1,38$ & 18,48 & $-1,55$ & 2,42 & 18,48 & 10,54 & 21,93 \\
\hline & & \pm & \pm & $\neq$ & $=$ & $\neq$ & $=$ & \pm & $=$ \\
\hline & & $\begin{array}{l}0,01 \\
7,78\end{array}$ & $\begin{array}{c}0,15 \\
10,12\end{array}$ & $\begin{array}{l}0,15 \\
8.81\end{array}$ & $\begin{array}{l}0.04 \\
6.56\end{array}$ & $\begin{array}{l}0,02 \\
7,59\end{array}$ & $\begin{array}{l}0,02 \\
6,75\end{array}$ & $\begin{array}{c}0,14 \\
10,40\end{array}$ & $\begin{array}{l}0.02 \\
8.90\end{array}$ \\
\hline & \multirow{2}{*}{ Glucan } & $=$ & $\stackrel{10}{=}$ & \pm & \pm & $=$ & $=$ & $=$ & $\stackrel{8,0}{=}$ \\
\hline & & 0,00 & 0.13 & 0,04 & 0.65 & 0.17 & 0.48 & 1.47 & 0,35 \\
\hline & \multirow[t]{2}{*}{ Xylan } & $-11,39$ & $-7,92$ & $-12,87$ & $-1,98$ & $-10,40$ & $-14,85$ & $-10,40$ & $-10,89$ \\
\hline & & $=$ & \pm & \pm & \pm & \pm & \pm & \pm & \pm \\
\hline & \multirow[t]{3}{*}{ Mannan } & 7,95 & 13,25 & 14,57 & 26,49 & $-3,31$ & 1,32 & $-25,17$ & 3,97 \\
\hline & & \pm & $=$ & $=$ & $=$ & $=$ & $\neq$ & $=$ & $=$ \\
\hline & & & 0.04 & 0.10 & 0.01 & 0,09 & 0,05 & 0,16 & 0,00 \\
\hline & \multirow{2}{*}{$\begin{array}{l}\text { Total } \\
\text { Carbohydra }\end{array}$} & 5,18 & 7,10 & 5,77 & 5,18 & 4,29 & 3,85 & 6,66 & 6,73 \\
\hline & & 0.00 & $\begin{array}{c} \pm \\
0.61\end{array}$ & 0.17 & $\stackrel{ \pm}{ \pm .78}$ & 0.35 & $\begin{array}{c} \pm \\
0.69\end{array}$ & $\stackrel{ \pm}{ \pm 73}$ & $\begin{array}{c} \pm \\
0.04\end{array}$ \\
\hline & \multirow[t]{3}{*}{$\mathrm{DP}^{\mathrm{s}}$} & 57,1 & 81,1 & 70,1 & 75,0 & 73,3 & 63,9 & 70,0 & $\begin{array}{l}0,049 \\
74,9\end{array}$ \\
\hline & & 7 & 6 & 3 & 6 & 1 & 3 & 0 & 8 \\
\hline & & \pm & \pm & \pm & $=$ & \pm & \pm & \pm & $=$ \\
\hline & \multirow[t]{3}{*}{ Cellulose } & 5,63 & 10,81 & 5,36 & 19,58 & 18,89 & 19,51 & 25,90 & 26,90 \\
\hline & & $=$ & \pm & $=$ & $=$ & \pm & \pm & \pm & \pm \\
\hline & & $\begin{array}{c}3,48 \\
20,07\end{array}$ & $\begin{array}{c}4,33 \\
39,19\end{array}$ & $\begin{array}{c}0,69 \\
27,89\end{array}$ & $\begin{array}{c}1,88 \\
38,52\end{array}$ & $\begin{array}{c}0,54 \\
43,16\end{array}$ & $\begin{array}{c}0.18 \\
39.85\end{array}$ & $\begin{array}{c}4,55 \\
51,18\end{array}$ & $\begin{array}{c}4,18 \\
57,41\end{array}$ \\
\hline & \multirow{2}{*}{ Lignin } & \pm & \pm & $=$ & \pm & $=$ & \pm & $=$ & $=$ \\
\hline & & 1.53 & 1.60 & 0.17 & 0.18 & 0.54 & 0.45 & 0.51 & 0.25 \\
\hline & \multirow[t]{2}{*}{ Arabinan } & 1,60 & $-0,80$ & $-1,60$ & $-2,41$ & $-0,80$ & $-1,60$ & 5,61 & 11,23 \\
\hline & & \pm & \pm & $=$ & \pm & $=$ & \pm & $=$ & \pm \\
\hline & \multirow[t]{3}{*}{ Galactan } & 18,83 & $\begin{array}{l}0,01 \\
23,32\end{array}$ & 36,44 & 26,42 & 29,71 & $\begin{array}{l}0,02 \\
16,58\end{array}$ & 29,53 & 38,51 \\
\hline & & \pm & \pm & \pm & \pm & \pm & \pm & \pm & \pm \\
\hline & & 0,06 & 0.02 & 0,04 & 0.03 & 0,05 & 0.03 & 0,07 & 0,02 \\
\hline & \multirow[t]{2}{*}{ Glucan } & 4,03 & 7,31 & 13,68 & 8,53 & 11,72 & 13,21 & 11,25 & 9,37 \\
\hline & & 0.87 & \pm & \pm & $=$ & \pm & \pm & \pm & $\stackrel{ \pm}{0.48}$ \\
\hline & \multirow[t]{3}{*}{ Xylan } & $-6,44$ & $-11,88$ & $-23,76$ & $-17,82$ & $-15,35$ & $-19,80$ & $-14,85$ & $-10,40$ \\
\hline & & \pm & $\neq$ & & \pm & \pm & $=$ & $=$ & $=$ \\
\hline & & 0.04 & 0.09 & 0.00 & 0.09 & 0.04 & 0,00 & 0.17 & 0.13 \\
\hline & \multirow[t]{2}{*}{ Mannan } & 10,60 & 14,57 & $-10,60$ & $-1,99$ & 15,89 & $-16,56$ & 0,66 & $-12,58$ \\
\hline & & $\stackrel{ \pm}{0.07}$ & \pm & \pm & \pm & \pm & $=$ & $=$ & $=$ \\
\hline & Total & 3,03 & 4,96 & 8,43 & 6,22 & 8,21 & 7,84 & 7,77 & 7,32 \\
\hline & Carbohydra & $=$ & & \pm & $=$ & \pm & $=$ & $=$ & $=$ \\
\hline & te & 1.00 & 0,30 & 0.26 & 0,82 & 0.65 & 0.87 & 1.60 & 0,30 \\
\hline & $\mathrm{DP}^{\mathrm{s}}$ & 38,2 & 20,9 & 52,7 & 42,8 & 37,7 & 44,9 & 26,9 & 36,0 \\
\hline & & 8 & 8 & 5 & 3 & 3 & 9 & 0 & 3 \\
\hline & & \pm & \pm & $=$ & \pm & $=$ & $=$ & \pm & \pm \\
\hline & & & & & & & & 0.35 & 0.16 \\
\hline
\end{tabular}

The data in Table 2, shows that the average percent losses in hemicelluloses (total carbohydrate) at the end of the incubation were $6,73 \%$ and $7,32 \%$ for Pleurotus ostreatus and Trametes versicolor, respectively. Glucan, galactan, and arabinan were the most noticeable hemicellulose components depleted by both fungi. In contrast to cellulose, the structure of hemicelluloses contains heteropolysaccharides constituents (Sjöström 1993, Kubicek 2013). One of the functions of hemicelluloses is protecting the 
cellulose microfibrils by providing physical barriers against hydrolytic enzymes. Hence, removal of the hemicellulose components from the cellulose microfibrils facilitates access of fungal hydrolytic enzymes to cellulose (Yang and Wyman 2004). Since the arabinan and galactan are side chain elements of xylan and mannan; they are very susceptible to degradation (Timell 1967). It has been suggested that they may be attacked before the main chain of the polymer (Curling et al. 2002). Therefore, the full decomposition of hemicelluloses requires the activation of special enzymes such as endo- $\beta-(1,4)-$ xylanase and $\beta$-xylosidase (Eriksson et al. 1990, Kubicek 2013). Overall, hemicelluloses were the most degraded polymers in beech wood exposed to both fungi as shown in Table 2. Determination of the total carbohydrate showed similar reduction for beech exposed to both fungi as well as their ability to produce specialized enzymes for the decomposition of wood cell walls.

As presented in Table 2, the lignin content declined uniformly during the incubation. Moreover, this data indicates that both test fungi tended to consume lignin more than cellulose. This is in agreement with the literature (Eaton and Hale 1993, Schmidt 2006), which indicates that both fungi are capable of degrading lignin more rapidly than carbohydrates. Lignin is a phenolic polymer that confers strength to plant cell walls, as well as serving as protection against pathogens (Eriksson et al. 1990, Eaton and Hale 1993, Schmidt 2006). In general, obtaining nutrients through plant cell wall during the decomposition mechanisms is a fundamental strategy for success of many microorganisms. For example, saprophytic fungi inhabit dead organic materials like decaying wood. In order to acquire energy from these materials, both fungi need to produce enzymes in order to degrade a majority of plant cell wall polysaccharides present in the biomass.

\section{Microscopic evaluations}

The series of micrographs of decayed woods in Figure 2 showed that the decay patterns caused by the two test fungi are very similar. In addition, the diagnostic features of decay represent simultaneous white-rot for both fungi. The arrows denote fiber cell walls which have thinned due to fungal attack, indicating that all cell wall polymers are degraded by the fungi. This means that not only both fungi are capable of degrading lignin and hemicelluloses, but also they can attack cellulose polymer as well. The decomposition of $\mathrm{S}_{2}$ and $\mathrm{S}_{3}$ layers and the remainder of only a thin middle lamella (Figure 1, Figure $3 \mathrm{~A}$ and Figure 3B) are the result of the fungi using all of the cell wall components, which has previously been reported (Liese 1970, Wilcox 1973, Schwarze et al. 2004, Schmidt 2006, Schwarze 2007, Kubicek 2013). When decay develops throughout the xylem, previously tiny bore holes on the cell wall coalesce together and become ruptures in the cell walls (Figure 1C and Figure 1D; arrowheads). Erosion along with the reducing of the fiber's wall thickness are further evidences of similar patterns of decay by studied fungi. In simultaneous white-rot decay patterns, the decay occurs in vicinity of the hyphae, with subsequent formation of erosion troughs where the hyphae are growing on the cell walls (Wilcox 1973, Anagnost 1998, Schwarze et al. 2004, Schwarze 2007, Kubicek 2013, Bari et al. 2015c, Kim et al. 2015). In the case of samples decayed with Pleurotus ostreatus, the process and features of decay are similar for most components of the wood. However, in very confined areas of one sample, anatomical diagnosis of selective white-rot decay was also observed, e.g. separation of the cells, while the secondary walls remained almost intact (Figure 2). Complete decomposition of ray parenchyma cells (arrows) as well as degradation of the cell walls and vessels (arrowheads) occurred due to severe degradation of cell wall components (Figure 3C, Figure 3D). Separation of the ray cell walls along with vessel lumina (arrows) and serious decomposition of woody structure (arrowheads) took place causing massive consumption of cell wall components (Figure 3E and Figure 3F). It has been reported that some white-rot fungi are capable of optimizing their decomposition strategy by changing from simultaneous to selective decay or selectively digest lignin in one place of the sample and show symptoms of simultaneous decay at the other place of the same sample (Hartig 1878, Nagadesi et al. 2013, Bari et al. 2015c). The switching in fungal behaviors, therefore, may causes changes in lingocellulolytic enzyme activity during the degradation of woody materials (Sunardi et al. 2016). 


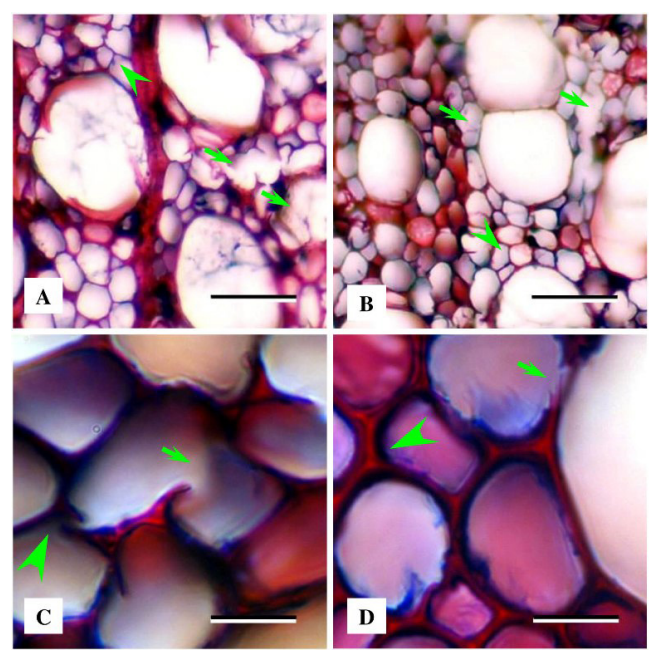

Figure 1. Light microscopy from transverse sections showing decay patterns in Oriental beech wood samples by two white-rot fungi; A, C: Pleurotus ostreatus; B, D: Trametes versicolor. a and b: Eroding along with thinning (arrowheads) and ruptured cell walls as well as hyphal colonization of cell lumens (arrows). C and D: Decomposition and removing of cell walls (arrows) as well as eroding and thinning of cell walls (arrowheads), while the middle lamella remains intact even at advanced stages of decay.

Scale bars in A, B: $30 \mu \mathrm{m} ; \mathrm{C}, \mathrm{D}: 15 \mu \mathrm{m}$.
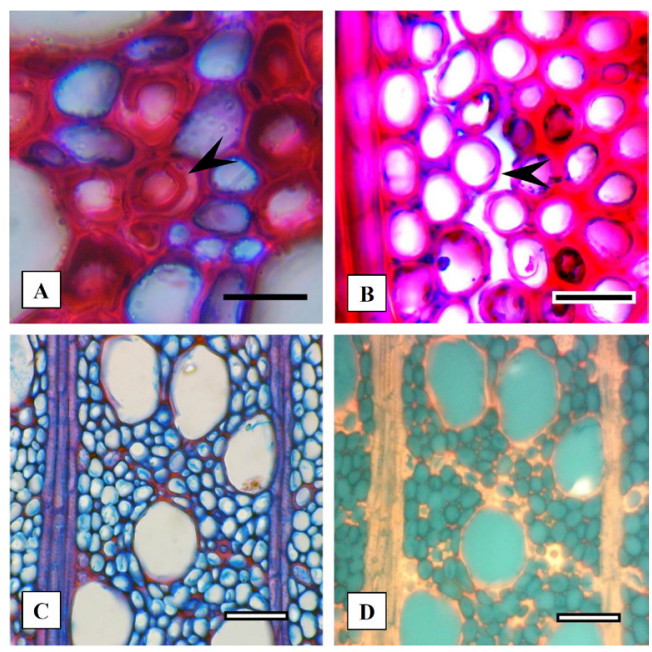

Figure 2. Oriental beech wood decayed by two white-rot fungi; a, b: Pleurotus ostreatus; c, d: Trametes versicolor under bright field (A-C) and UV light (D). Separation of secondary wall of a tracheid in cross section (A) and ray parenchyma cells in tangential section (B) of decayed wood resembling selective degradation. Under bright field, most of the tissue fibers are degraded while vessel walls show higher resistance with their red-stained color (C). This can be confirmed by viewing the same sample under UV light (D).

Scale bars in A, B: $20 \mu \mathrm{m} ; \mathrm{C}, \mathrm{D}: 50 \mu \mathrm{m}$. 

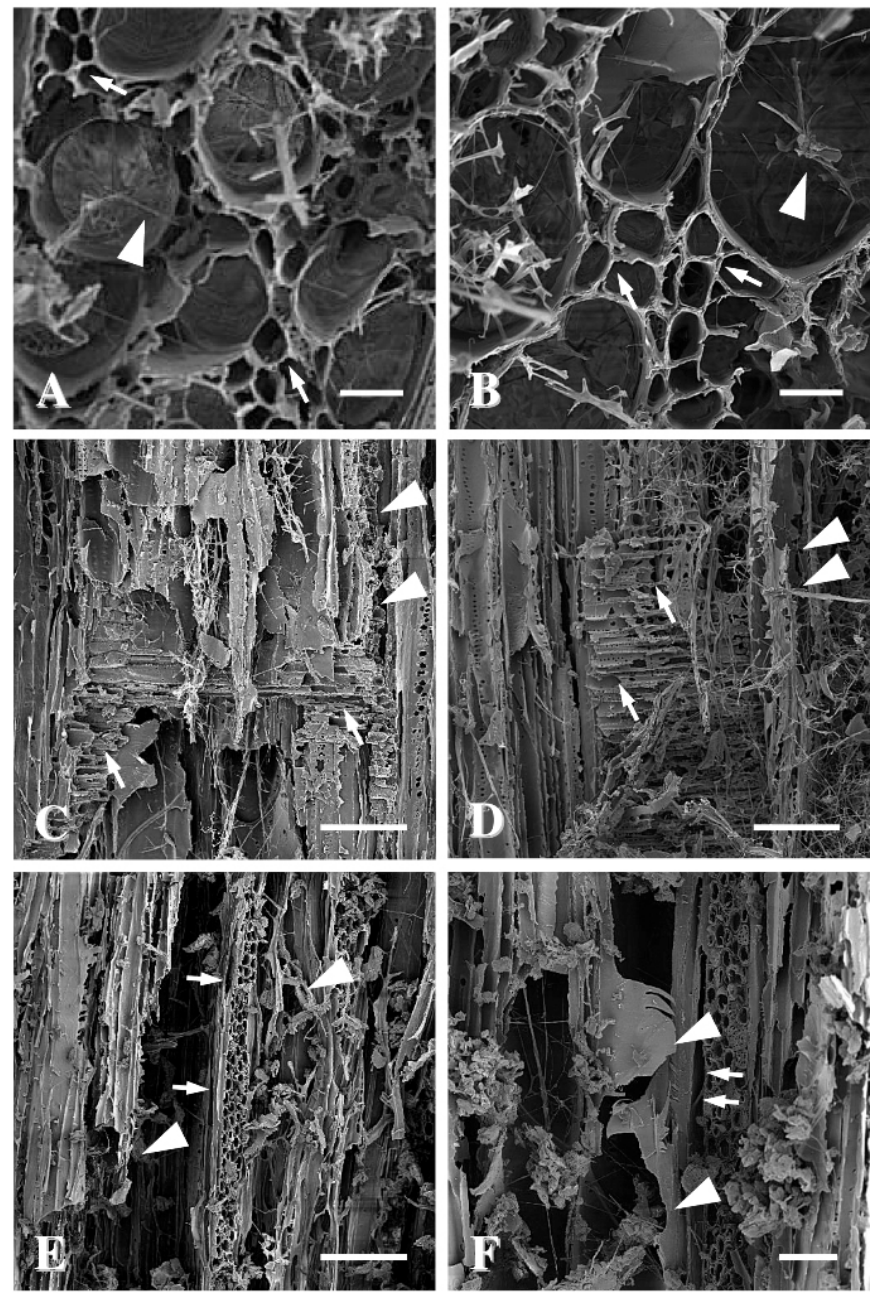

Figure 3. Scanning electron micrographs of beech wood degradation after 120 days of exposure to the white-rot fungi; Pleurotus ostreatus (A,C\&E); Trametes versicolor (B,D\&F). A\&B: cross sections: Severe eroded and thinned cell walls (arrows) as well as colonization of hyphae in cell lumina (arrowheads). C\&D: radial sections: Complete decomposition of ray parenchyma (arrows) as well as deconstruction of cell walls and vessels (arrowheads) due to severe degradation of cell walls chemical materials. E\&F: tangential section: separation of ray wall with vessels lumina (arrows) and serious decomposition of woody structure (arrowheads) due to massive consumption of cell wall chemicals.

A\&B: bar $20 \mu \mathrm{m} ; \mathrm{C}, \mathrm{D}, \mathrm{E}, \mathrm{F}:$ bar $100 \mu \mathrm{m}$.

\section{FTIR spectroscopy}

The IR-spectra of white-rotted wood show changes of peaks in the fingerprint region (between $1800-600 \mathrm{~cm}^{-1}$ ) for different stages of decay for both test fungi (Figure 4). As shown for the IR-spectra of the un-decayed beech wood, there is strong bond stretching by hydroxyl groups $(\mathrm{O}-\mathrm{H})$ at $3500-3300$ $\mathrm{cm}^{-1}$, prominent symmetric $\mathrm{C}-\mathrm{H}$ bond stretching in aromatic methoxyl, methyl and methylene groups around $2885 \mathrm{~cm}^{-1}$, and many well-defined peaks in the fingerprint region (between 1800-600 $\mathrm{cm}^{-1}$ ). Detailed information on assigned peaks is shown in Table 3. Comparison between the peaks obtained from different stages of fungal decay with the un-decayed wood revealed disappearance of some peaks and appearance of new peaks after exposure to both fungi, which are prominent indications of new bonds generated from altered cell wall constituents and their cleaved structures (Figure 4). 

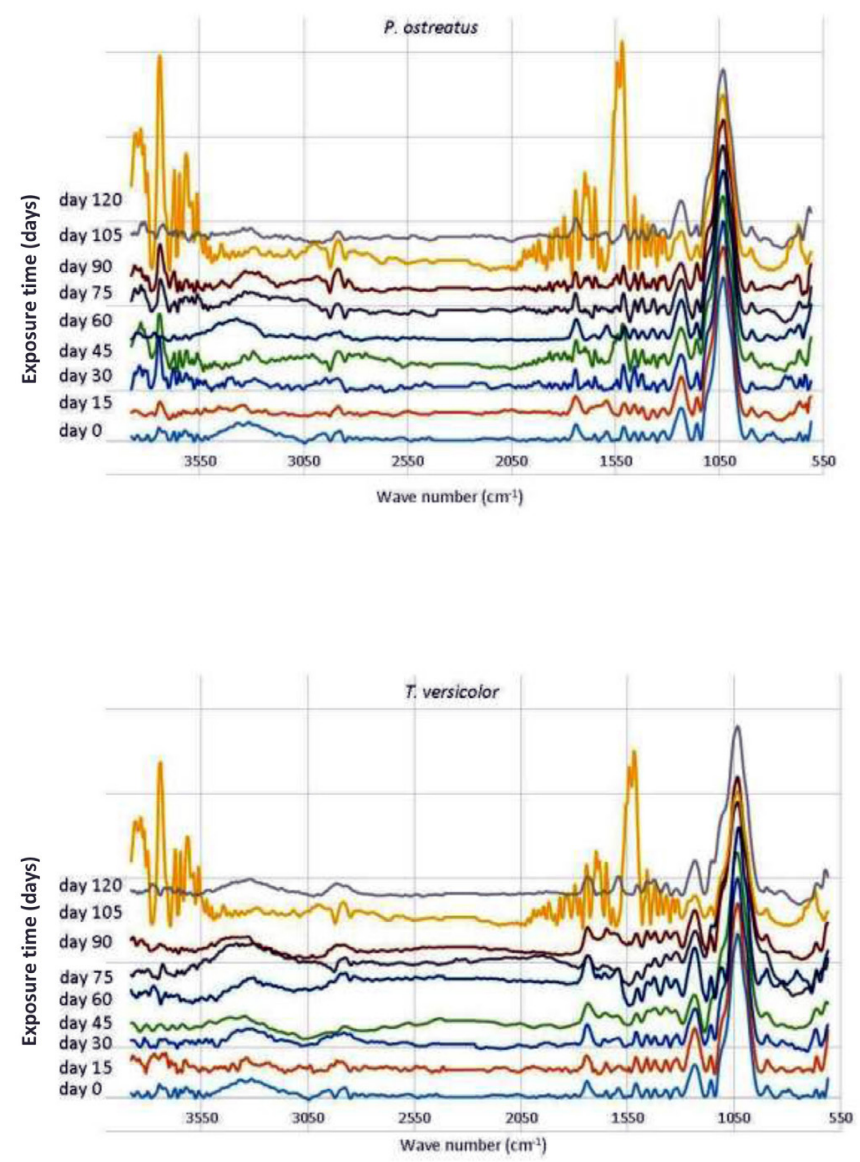

Figure 4. IR-spectra for beech wood decayed by two white rot fungi, P. ostreatus and T. versicolor, during different periods of exposure. 
Table 3. IR assignment in decayed wood (Popescu et al. 2007).

\begin{tabular}{|c|c|c|}
\hline $\begin{array}{c}\text { Wavenumber } \\
\left(\mathrm{cm}^{-1}\right)\end{array}$ & Band assignment $^{\mathrm{c}}$ & References \\
\hline $3580-3550$ & Free $\mathrm{OH}(6)$ and $\mathrm{OH}(2)$, weakly absorbed water & $\begin{array}{l}\text { Hinterstosser and Salmen (2000); Kondo (1997); } \\
\text { Bellamy (1975) }\end{array}$ \\
\hline $3460-3405$ & $\mathrm{O}(2) \mathrm{H} . . \mathrm{O}(6)$ intramolecular hydrogen bonds & $\begin{array}{l}\text { Tashiro and M. Kobayashi (1991); Pandey and } \\
\text { Pitman (2003); Schwanninger et al. (2004); } \\
\text { Hinterstosser and Salmen (2000) }\end{array}$ \\
\hline $3375-3340$ & $\begin{array}{l}\mathrm{O}(3) \mathrm{H} . . \mathrm{O}(5) \text { intramolecular hydrogen bonds } \\
\text { in cellulose }\end{array}$ & $\begin{array}{l}\text { Pandey and Pitman (2003); Schwanninger et al. } \\
\text { (2004); Carrillo et al. (2004) }\end{array}$ \\
\hline $3310-3230$ & $\begin{array}{l}\mathrm{O}(6) \mathrm{H} . . \mathrm{O}(3) \text { intermolecular hydrogen bonds } \\
\text { in cellulose } 4 \text {, }\end{array}$ & $\begin{array}{l}\text { Mann and Marrinan (1956); Sugiyama et al. } \\
\text { (1991); Schwanninger et al. (2004); Hinterstosser } \\
\text { and Salmen (2000) }\end{array}$ \\
\hline 3175 & $\begin{array}{l}\text {-OH stretching intramolecular hydrogen bonds } \\
\text { in cellulose II }\end{array}$ & Schwanninger et al. (2004); Carrillo et al. (2004) \\
\hline & Symmetric CH stretching in aromatic & $\begin{array}{l}\text { Pandey and Pitman (2003); Schwanninger et } \\
\text { al.(2004); Hinterstosser and Salmen (2000); }\end{array}$ \\
\hline $2938-2920$ & $\begin{array}{l}\text { methoxyl groups and in methyl and methylene } \\
\text { groups of side chains }\end{array}$ & $\begin{array}{l}\text { Kondo (1997); Bellamy (1975); Carrillo et al. } \\
\text { (2004) }\end{array}$ \\
\hline $2840-2835$ & Asymmetric $\mathrm{CH}$ stretching of side chains & $\begin{array}{l}\text { Pandey and Pitman (2003); Schwanninger et al. } \\
\text { (2004); Hinterstosser and Salmen (2000); Kondo } \\
\text { (1997); Bellamy (1975); Carrillo et al. (2004) }\end{array}$ \\
\hline $1770-1760$ & $\mathrm{C}=\mathrm{O}$ stretching in conjugated ketones & $\begin{array}{l}\text { Colom et al. (2003); Pandey and Pitman (2003); } \\
\text { Mohebby (2005); Schwanninger et al. (2004) }\end{array}$ \\
\hline $1740-1720$ & $\mathrm{C}=\mathrm{O}$ stretch in unconjugated ketones & $\begin{array}{l}\text { Colom et al. (2003); Pandey and Pitman (2003); } \\
\text { Mohebby (2005); Schwanninger } \text { et al. (2004) }\end{array}$ \\
\hline $1650-1640$ & Water associated with lignin or cellulose & $\begin{array}{l}\text { Pandey and Pitman (2003); Schwanninger } \text { et al. } \\
(2004)\end{array}$ \\
\hline $1610-1590$ & $\mathrm{C}=\mathrm{C}$ stretching of the aromatic ring $(\mathrm{S})$ & $\begin{array}{l}\text { Pandey and Pitman (2003); Schwanninger et al. } \\
(2004)\end{array}$ \\
\hline $1515-1505$ & $\mathrm{C}=\mathrm{C}$ stretching of the aromatic ring $(\mathrm{G})$ & $\begin{array}{l}\text { Pandey and Pitman (2003); Mohebby (2005); } \\
\text { Schwanninger et al. (2004) }\end{array}$ \\
\hline $1470-1455$ & $\begin{array}{l}\mathrm{C}-\mathrm{H} \text { asymmetric deformation in }-\mathrm{OCH}_{3}, \mathrm{CH}_{2} \\
\text { in pyran ring symmetric scissoring }\end{array}$ & $\begin{array}{l}\text { Pandey and Pitman (2003); Mohebby (2005); } \\
\text { Schwanninger et al. (2004); Carrillo et al. (2004) }\end{array}$ \\
\hline $1430-1422$ & $\mathrm{C}-\mathrm{H}$ asymmetric deformation in $-\mathrm{OCH}_{3}$ & $\begin{array}{l}\text { Pandey and Pitman (2003); Mohebby (2005); } \\
\text { Schwanninger et al. (2004); Carrillo et al. (2004) }\end{array}$ \\
\hline $1375-1365$ & $\begin{array}{l}\text { CH bending in cellulose I and cellulose II and } \\
\text { hemicellulose }\end{array}$ & $\begin{array}{l}\text { Pandey and Pitman (2003); Mohebby 2005; } \\
\text { Schwanninger et al. (2004); Carrillo et al. (2004) }\end{array}$ \\
\hline $1335-1320$ & $\begin{array}{l}\mathrm{C}_{1}-\mathrm{O} \text { vibrations in } \mathrm{S} \text { derivatives, } \mathrm{CH} \text { in-plane } \\
\text { bending in cellulose I and cellulose II }\end{array}$ & $\begin{array}{l}\text { Colom et al. (2003); Pandey and Pitman (2003); } \\
\text { Mohebby (2005); Schwanninger et al. (2004); } \\
\text { Carrillo et al. (2004) }\end{array}$ \\
\hline 1315 & $\mathrm{CH}_{2}$ wagging in cellulose I and cellulose II & Schwanninger et al. (2004); Carrillo et al. (2004) \\
\hline $1282-1277$ & $\mathrm{CH}$ deformation in cellulose I and cellulose II & Schwanninger et al. (2004) \\
\hline 1268 & $\begin{array}{l}\text { Guaiacyl ring breathing, } \mathrm{C}-\mathrm{O} \text { linkage in } \\
\text { guaiacyl aromatic methoxyl groups }\end{array}$ & $\begin{array}{l}\text { Pandey and Pitman (2003); Schwanninger et al. } \\
(2004)\end{array}$ \\
\hline $1235-1230$ & $\begin{array}{l}\text { Syringyl ring breathing and } \mathrm{C}-\mathrm{O} \text { stretching in } \\
\text { lignin and xylan }\end{array}$ & $\begin{array}{l}\text { Pandey and Pitman (2003); Mohebby (2005); } \\
\text { Schwanninger } \text { et al. (2004) }\end{array}$ \\
\hline $1205-1200$ & $\begin{array}{l}\text { OH in-plane bending in cellulose I and } \\
\text { cellulose II }\end{array}$ & Schwanninger et al. (2004) \\
\hline $1162-1125$ & $\begin{array}{l}\mathrm{C}-\mathrm{O}-\mathrm{C} \text { asymmetric stretching in cellulose I } \\
\text { and cellulose II }\end{array}$ & $\begin{array}{l}\text { Pandey and Pitman (2003); Mohebby (2005); } \\
\text { Schwanninger et al. (2004); Carrillo et al. (2004) }\end{array}$ \\
\hline 1140 & $\begin{array}{l}\text { Aromatic } \mathrm{C}-\mathrm{H} \text { in-plane deformation; typical } \\
\text { for } \mathrm{G} \text { units, where } \mathrm{G} \text { condensed. } \mathrm{G} \text { etherified }\end{array}$ & $\begin{array}{l}\text { Pandey and Pitman (2003); Schwanninger et al. } \\
(2004)\end{array}$ \\
\hline $1128-1110$ & $\begin{array}{l}\text { Aromatic } \mathrm{C}-\mathrm{H} \text { in-plane deformation (typical } \\
\text { for } \mathrm{S} \text { units), } \mathrm{C}=\mathrm{O} \text { stretch }\end{array}$ & $\begin{array}{l}\text { Pandey and Pitman (2003); Mohebby (2005); } \\
\text { Schwanninger } \text { et al. (2004) }\end{array}$ \\
\hline $1086-1075$ & $\begin{array}{l}\mathrm{C}-\mathrm{O} \text { deformation in secondary alcohols and } \\
\text { aliphatic ethers }\end{array}$ & Schwanninger et al. (2004) \\
\hline $1060-1015$ & $\begin{array}{l}\mathrm{C}-\mathrm{O} \text { valence vibration mainly from } \mathrm{C}(3)-\mathrm{O}(3) \\
\mathrm{H}\end{array}$ & $\begin{array}{l}\text { Pandey and Pitman (2003); Schwanninger et al. } \\
\text { (2004); Carrillo et al. (2004) }\end{array}$ \\
\hline $1047-1004$ & $\mathrm{C}-\mathrm{O}$ stretching in cellulose I and cellulose II & $\begin{array}{l}\text { Pandey and Pitman (2003); Mohebby (2005); } \\
\text { Schwanninger et al. (2004); Carrillo et al. (2004) }\end{array}$ \\
\hline $996-985$ & $\mathrm{C}-\mathrm{O}$ valence vibration & Schwanninger et al. (2004) \\
\hline 970 & $=\mathrm{CH}$ out-of-plane deformation (trans) & Schwanninger et al. (2004) \\
\hline $930-915$ & $\begin{array}{l}\text { Aromatic } \mathrm{C}-\mathrm{H} \text { out-of-plane deformations, } \\
\text { pyran ring vibration }\end{array}$ & Schwanninger et al. (2004) \\
\hline
\end{tabular}

S: syringyl; G: guaiacyl 
Subtraction of the un-decayed peaks clearly shows the presence of newly formed peaks for the decayed wood (Figure 5, Figure 6, Figure 7, Figure 8, Figure 9). In Figure 5, Figure 6, Figure 7, Figure 8 , Figure 9, the baselines (line zero) indicates changes in the decayed wood in comparison to the undecayed wood. The subtracted peaks above the baseline showed a decrease in intensity of the present peaks and the peaks below the baseline indicate an increase of the present peaks as well as appearance of new bands due to fungal attack. When there is no difference between the peaks, the subtracted peak intensities are zero. In this situation, the subtracted peaks are located on baselines which indicate no changes in the wood during fungal attack. The spectra for the wood decayed by both fungi during the early stages of exposure revealed fewer alterations in wood chemistry which is probably due to reduced decay; while the wood attacked for 45 days revealed the appearance of new peaks $\left(1800-400 \mathrm{~cm}^{-1}\right)$; especially for hemicelluloses and lignin (Figure 6).
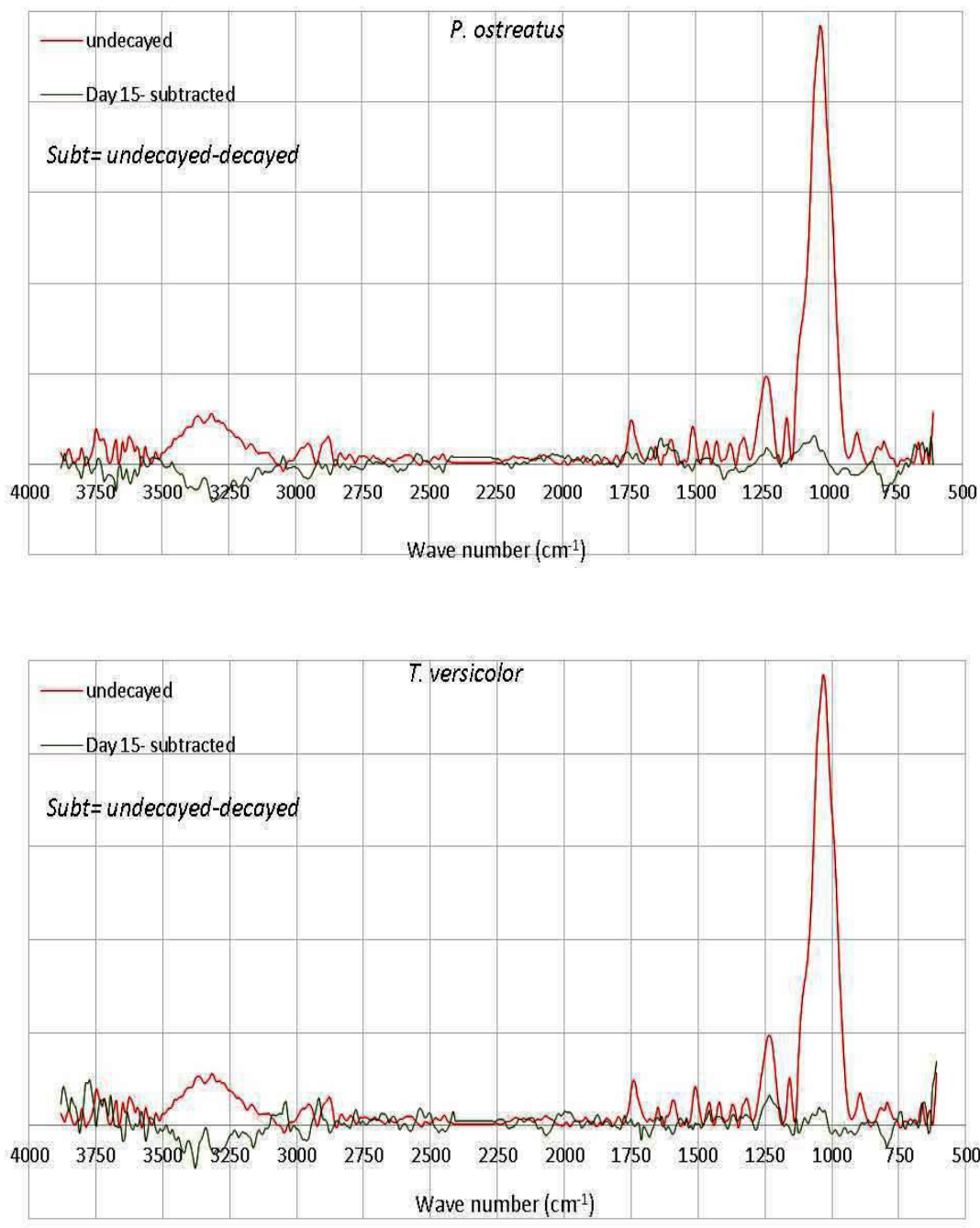

Figure 5. Subtracted IR-spectra for beech wood decayed by two white rot fungi, T. versicolor and $P$. ostreatus, during 15 days of fungal exposure. 

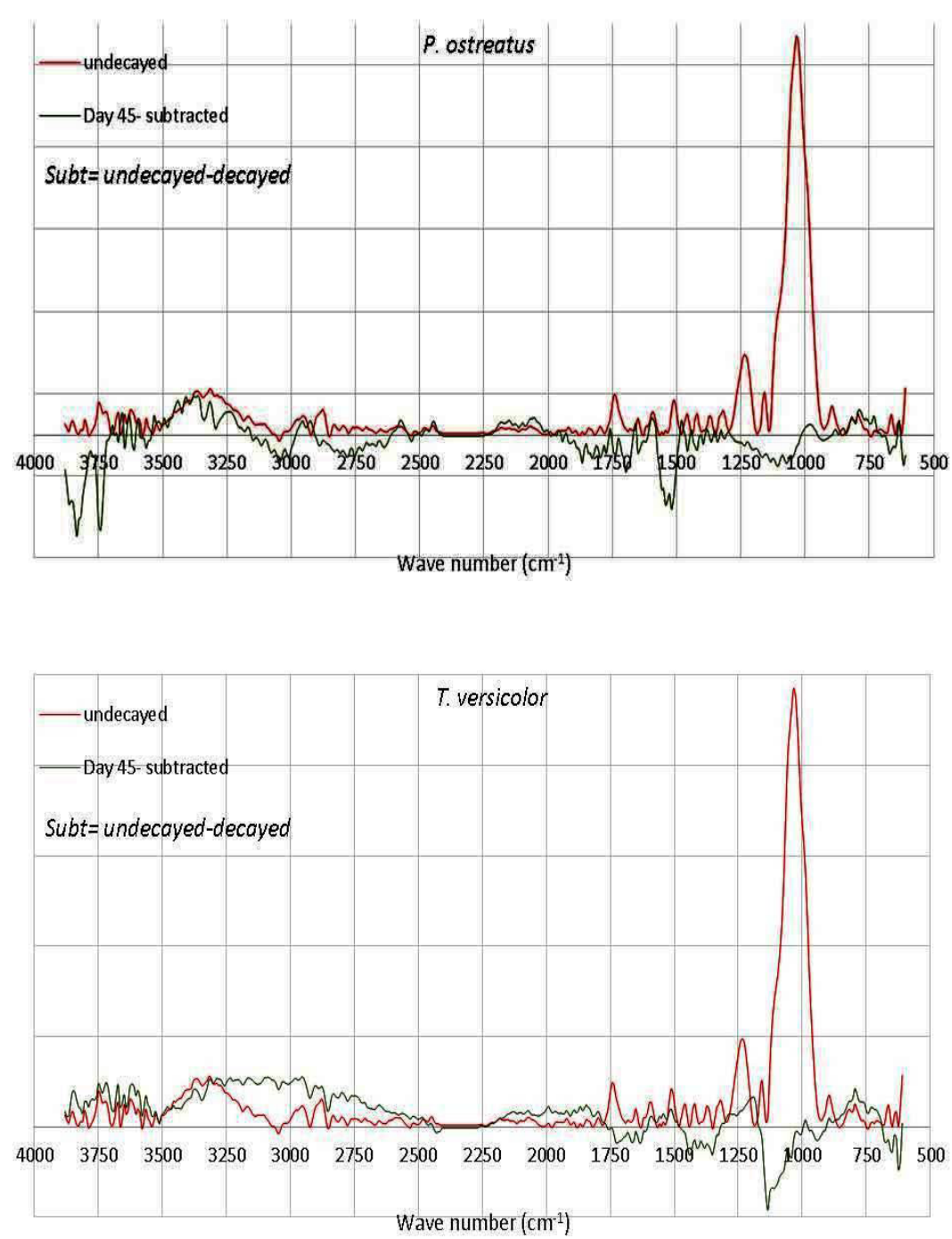

Figure 6. Subtracted IR-spectra for beech wood decayed by two white rot fungi, P. ostreatus and T. versicolor, during 45 days of fungal exposure. 

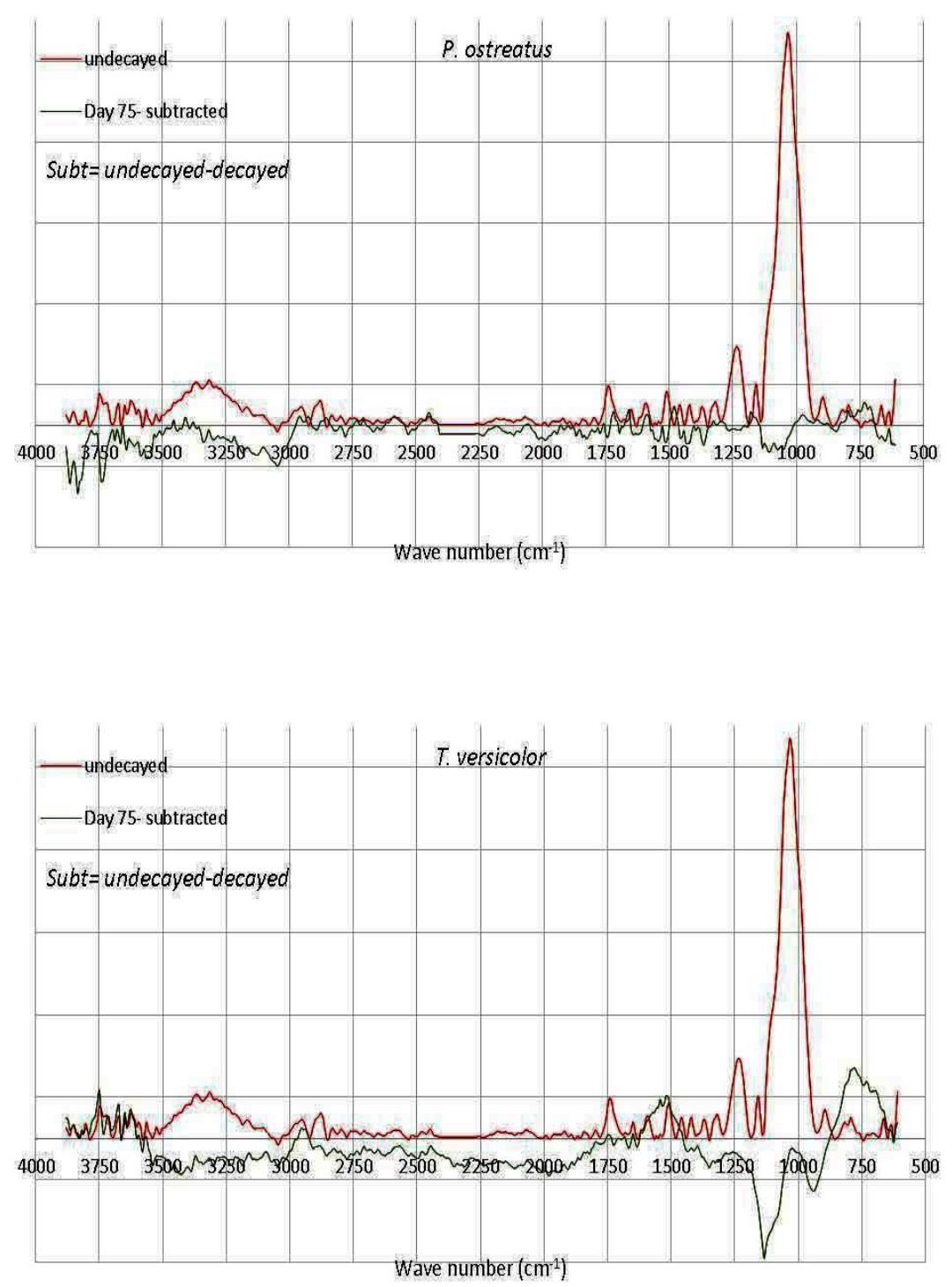

Figure 7. Subtracted IR-spectra for beech wood decayed by two white rot fungi, $P$. ostreatus and $T$. versicolor, during 75 days of fungal exposure. 

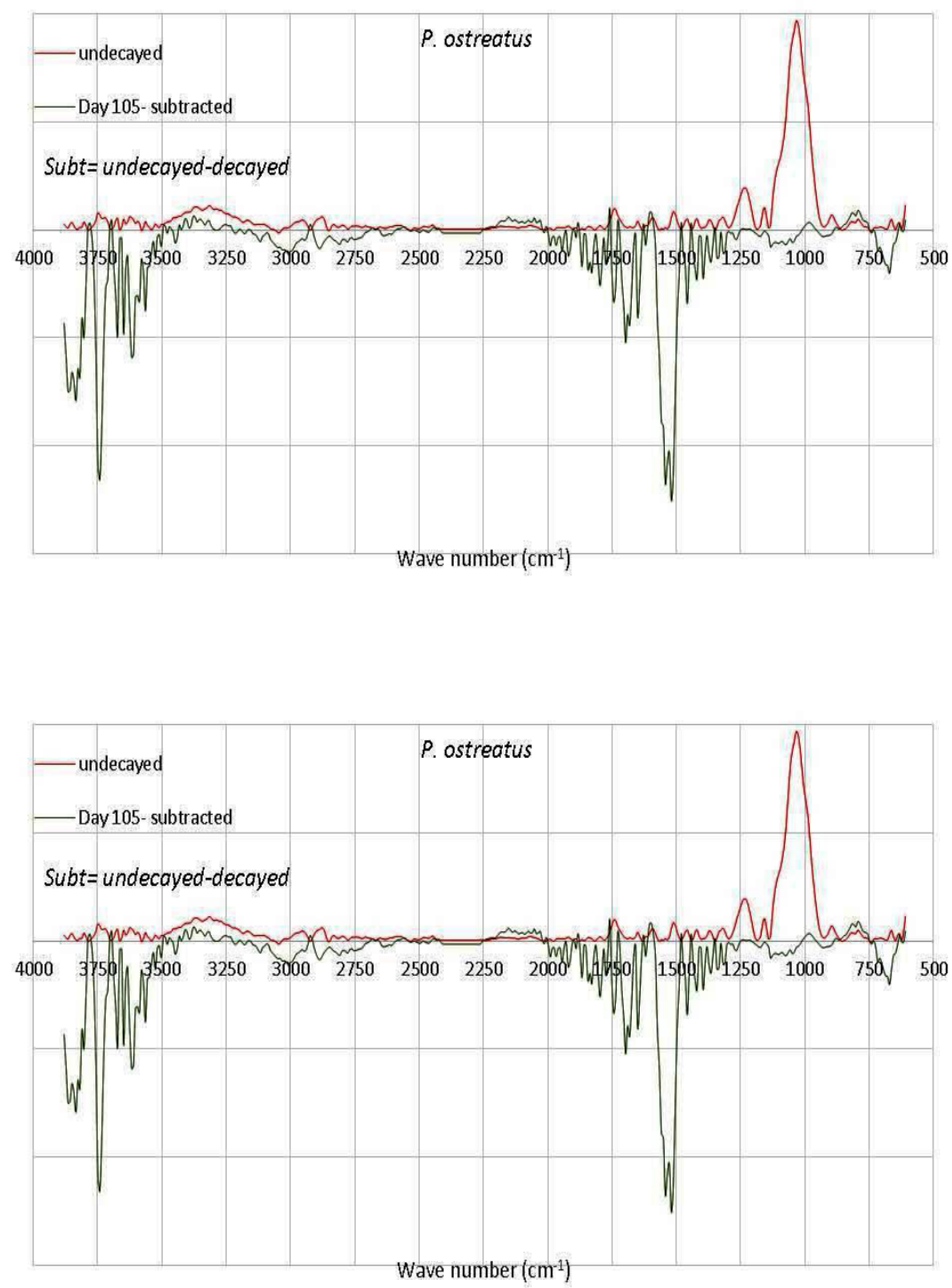

Figure 8. Subtracted IR-spectra for beech wood decayed by two white rot fungi, P. ostreatus and T. versicolor, during 105 days of fungal exposure. 

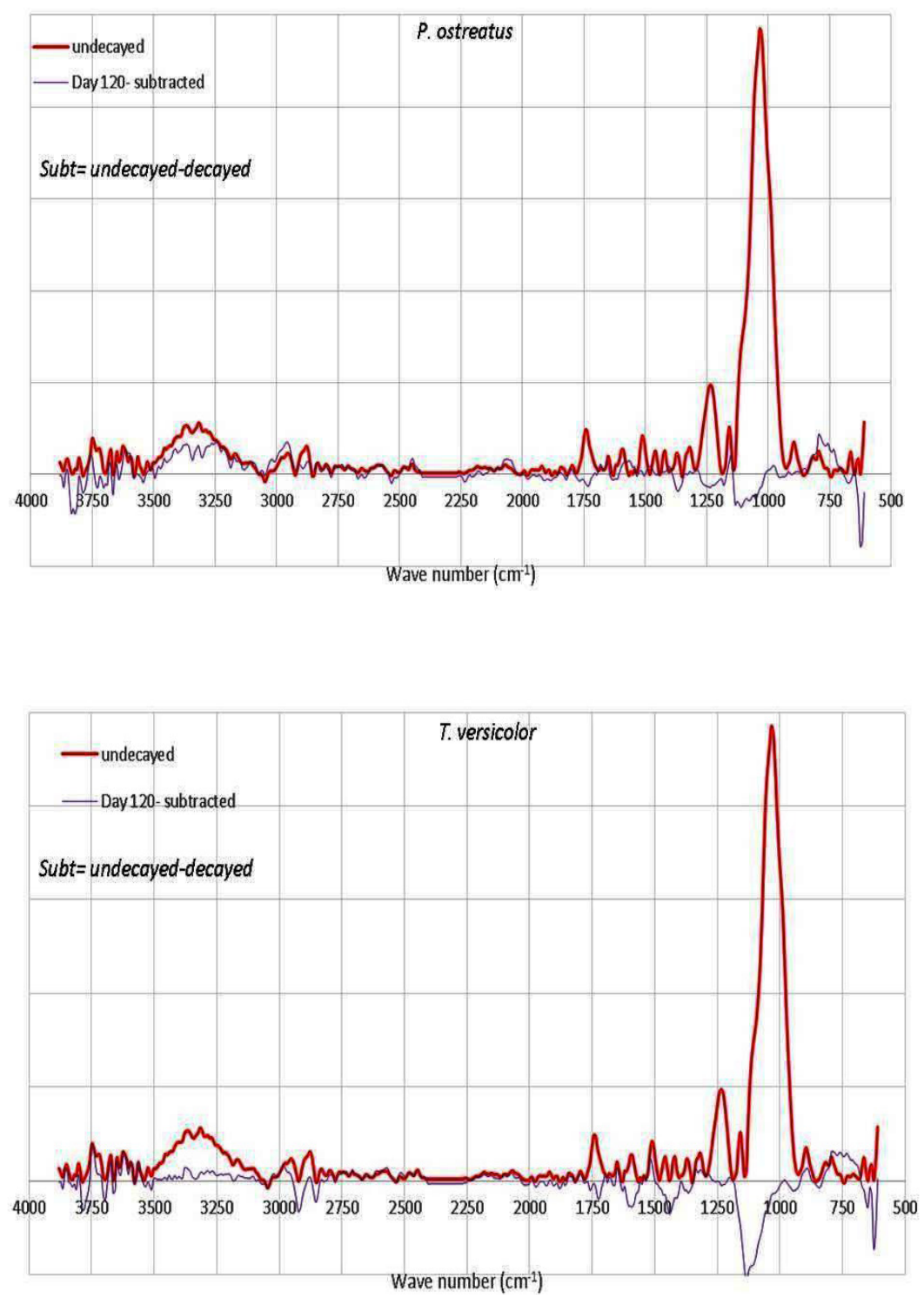

Figure 9. Subtracted IR-spectra for beech wood decayed by two white rot fungi, $P$. ostreatus and $T$. versicolor, during 120 days of fungal exposure. 
The spectra for the decayed wood exposed to both white-rot fungi for 45, 75 and 105 days revealed appearance of new peaks at $1800-1650 \mathrm{~cm}^{-1}$ and $1500-1300 \mathrm{~cm}^{-1}$. Furthermore, new peaks appeared at $1800-1300 \mathrm{~cm}^{-1}$ for wood decayed by both white-rot fungi within 105 days. Those peaks represent fingerprint regions for hemicelluloses (especially xylan) and aromatic skeletal $\mathrm{C}-\mathrm{H}$ as well as lignin derivatives. The new peaks indicate that new bands have developed due to breakdown of cell wall constituents, especially lignin and hemicelluloses. It is well known that white-rot fungi produce different types of hydrolyzing enzymes to dissolve lignin in wood cell walls as well as the middle lamella.

The new peaks disappeared for days 15, 75 and 120 (Figure 7, Figure 8, Figure 9). It is interesting to see considerable differences in spectra for decayed wood at days 105 and 120 (Figure 8, Figure 9). The new peaks appeared in wood exposed to the test fungi for 105 days (Figure 8) and disappeared at 120 days (Figure 9), indicating that both fungi degraded cell wall constituents until day 105 and then liberated them as small molecules. Afterwards, those molecules were assimilated as carbon sources by the fungi (Figure 9). Subsequently, fragments or non-degraded parts of the cell walls remained which are chemically similar to un-decayed wood. As shown in Figure 9, there are no substantial differences between spectra for decayed and un-decayed wood at this phase.

As Mohebby (2005) and Karim et al. (2017) stated that the white-rot fungus T. versicolor has the ability to remove most of the hemicelluloses adjacent to lignin and also partially remove the cellulose. According to the spectra assigned for the un-decayed wood (Table 3), the peaks related to hemicelluloses and lignin changed during fungal exposure, with partial changes in cellulose clearly indicating nonselective degradation of wood by both fungi. This phenomenon was also recently investigated and confirmed by microscopy and chemical studies for both fungi (Bari et al. 2015b, Bari et al. 2015c). Mohebby (2005) as well as and Pandey and Pittman (2003) studied chemical changes in wood decayed by $T$. versicolor using FTIR spectroscopy and found decreased intensities of bands for lignin and carbohydrates. In contrast to the white-rot, during in the brown-rot decay the selective removal of structural carbohydrate components take place and causes increasing the higher lignin/carbohydrate ratio as decay progresses (Bouslimi et al. 2014).

Comparison of the spectra of beech wood decayed by the two fungi used in this study after different periods of exposure showed considerable similarities, i.e., simultaneous appearance and disappearance of peaks. This suggests that both fungi use very similar mechanisms to attack wood. The authors conclude that these microscopic observations confirm the FTIR results.

Ratios of peak intensity at $1510 \mathrm{~cm}^{-1}(\mathrm{C}=\mathrm{C}$ stretching in lignin aromatic skeletal structure $)$ is presented in Figure 10 for both test fungi. The trends of the ratios vary similarly for both fungi during the exposure period with an increase at day 105 . This increase indicates that the $\mathrm{C}=\mathrm{C}$ band intensities in the decayed wood are higher than the un-decayed wood due to fungal attack, indicating that the lignin structure has been severely attacked by the test fungi at day 105 (Figure 4 and Figure 8).

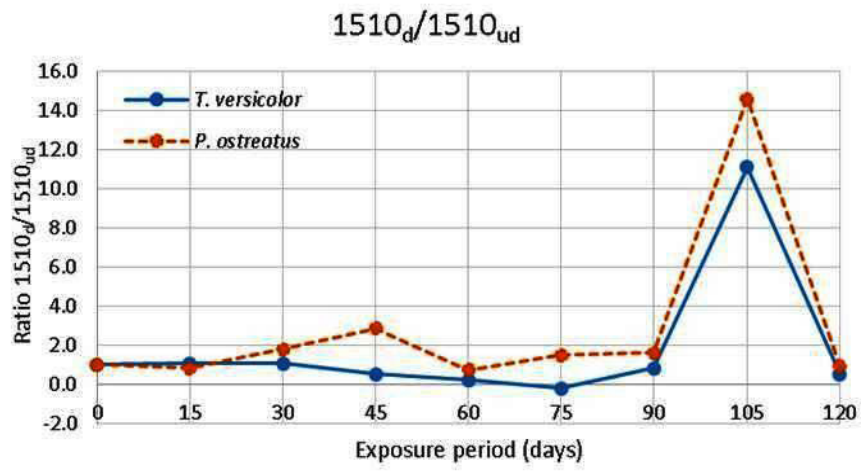

Figure 10. Intensity ratio for wave number $1510 \mathrm{~cm}-1(\mathrm{C}=\mathrm{C})$ of decayed to undecayed wood due to both fungi. 
The ratio of peaks at $1510 / 1158 \mathrm{~cm}^{-1}(\mathrm{C}=\mathrm{C}$ stretching in lignin and $\mathrm{C}-\mathrm{O}-\mathrm{C}$ stretching in cellulose, respectively) is shown in Figure 11. The ratios varied for both test fungi with an increase at day 105 of fungal exposure. The increase shows that the $\mathrm{C}=\mathrm{C}$ band intensities are higher than that of $\mathrm{C}-\mathrm{O}-\mathrm{C}$ at day 105 , indicating that severe attack of the lignin has been occurred compared to attack of the cellulose.

\section{$1510 / 1158$}

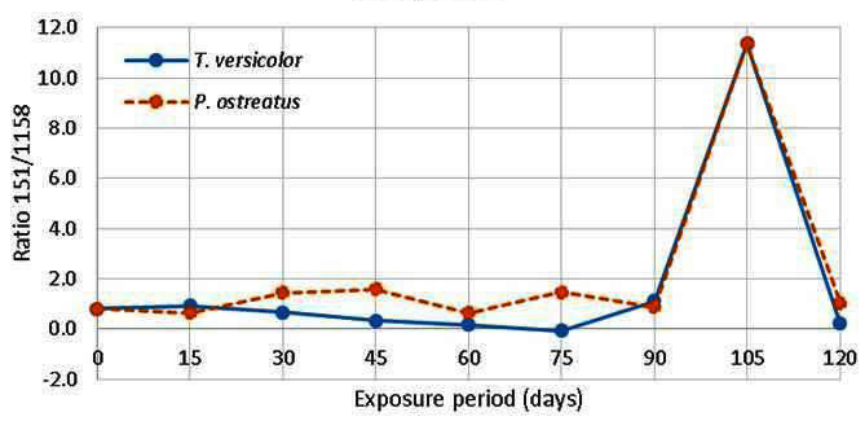

Figure 11. Intensity ratio for wave number $1510 \mathrm{~cm}-1(\mathrm{C}=\mathrm{C})$ to $1158 \mathrm{~cm}-1(\mathrm{C}-\mathrm{O}-\mathrm{C})$ in decayed wood due to both fungi.

The ratio of peaks of the wave numbers $1510 / 895 \mathrm{~cm}^{-1}$ is shown in Figure 12. The peak at wave number $895 \mathrm{~cm}^{-1}$ is assigned for $=\mathrm{C}-\mathrm{H}$ out of plane stretching which is related to lignin structure. There are similarities for both test fungi during exposure, with an increase occurring at day 105 . However, there are some different fluctuations in the peak ratio for $P$. ostreatus. This indicates that both fungi attack the wood with similar patterns; however, they sometimes use different strategies to attack lignin. Any increase in peak ratio indicates that lignin has been broken down, many bonds are cleaved, and new bonds appeared in the lignin structure. In this case, an increase of $=\mathrm{C}-\mathrm{H}$ bonds expressed as $\mathrm{C}=\mathrm{C}$ bonds which have already been cleaved in lignin, or the intermolecular bonds in lignin monomers have already been broken down during fungal attack. The results presented here as well as the microscopic observations confirm the above mentioned results; especially Figure 4 and Figure 8. In general, it can be seen that the lignin has been severely attacked util2 day 105 and the liberated materials have been assimilated before day 120. Because there are quite similarities between days 120 and 0 .

\section{$1510 / 895$}

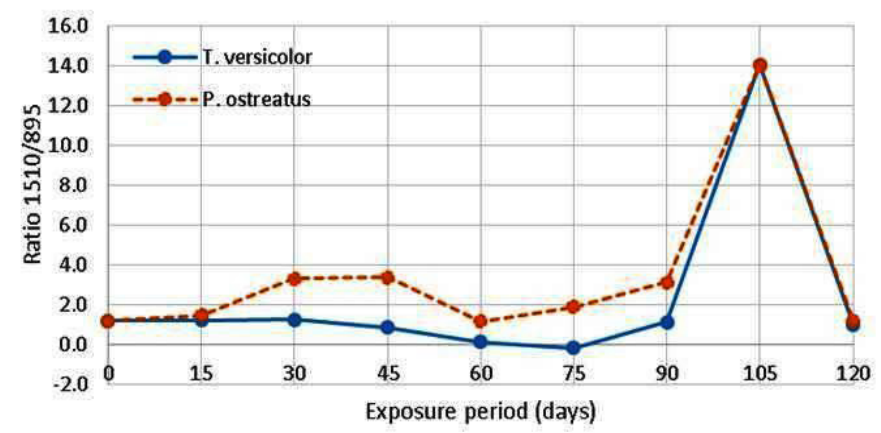

Figure 12. Intensity ratio for wave number $1510 \mathrm{~cm}-1(\mathrm{C}=\mathrm{C})$ to $895 \mathrm{~cm}-1$ (out of plane $=\mathrm{CH})$ in decayed wood due to both fungi. 


\section{CONCLUSIONS}

Both white rot fungi, Trametes versicolor and Pluerotus ostreatus, caused a similar rate of mass loss at each period of incubation with similar patterns of decay. The photochemical assessment elucidated changes in lignin and carbohydrates in beech wood and determined that both fungi are able to decay wood in a simultaneous patterns, which are also confirmed by results of the chemical analysis. Both the fungi attacked the lignin severely and consumed the liberated materials obtained from lignin and also carbohydrates (cellulose as well as hemicelluloses) throughout the decay process. Results of the chemical analyses are in accordance with the FTIR spectra. It is interesting observation that there are significant differences between spectra for decayed wood at days 105 and 120. Appearance of new peaks at until the day 105, confirmed any attacks in cell wall constituents and degradation of the cell wall polymers. Disappeared peaks for spectra at day 120 represents assimilation of the liberated materials during the cell wall degradation. According to the chemical analysis as well as the microscopic studies, we can conclude that both fungi have the capabilities to degrade all cell wall components. In spite of reports which are indicating that the fungus $P$. ostreatus is a selective white rotter, the observation here mostly indicated a simultaneous one. However, in very confined areas of xylem, anatomical diagnosis of selective decay was also observed. Overall, the results confirmed that both fungi are capable of producing simultaneous white rot.

\section{ACKNOWLEDGEMENTS}

The authors give their sincere thanks to Dr. N. Bahramifar from Tarbiat Modares University and Mr. Taheri from Payam-e Noor University of Sari for their cooperation in IR-spectra preparation.

\section{REFERENCES}

Adaskaveg, J.E; Gilbertson, R.L; Dunlap, M.R. 1995. Effects of incubation time and temperature on in vitro selective delignification of silver leaf oak by Ganoderma colossum. Appl Environ Microbiol 61: 138-144.

Aghajani, H.; Marvie Mohadjer, M.R.; Bari, E.; Ohno, K.M.; Asef, M.R. 2017. Assessing the biodiversity of wood decay fungi in northern forests of Iran. Proc. Natl. Acad. Sci., India, Sect. B Biol. Sci.

Anagnost, S.E. 1998. Light microscopic diagnosis of wood decay. IAWA J 19: 141-167.

Argyropoulos, D.S; Menachem, S.B. 1997. Lignin. Adv Biochem Eng Biotechnol 57: 127-158.

Baldrian, P. 2008. Enzymes of saprotrophic basidiomycetes. In: Boddy, L; Frankland, J.C; Van West, P. (Eds.), Ecology of Saprotrophic Basidiomycetes. Academic Press Elsevier, London: pp. 19-41.

Bari, E. 2014. Potential of biological degradation of oriental beech wood by the white-rot fungus Pleurotus ostreatus and the effects on mechanical and chemical properties there of and its comparison with standard the white-rot fungus Trametes versicolor. Dissertation, Sari Agriculture and Natural Resources University, Sari, Iran.

Bari, E.; Nazarnezhad, N.; Kazemi, SM.; Tajick Ghanbary, MA.; Mohebby, B.; Schmidt, O.; Clausen, CA. 2015a. Comparison of degradation capabilities of the white rot fungi Pleurotus ostreatus 
and Trametes versicolor. International Biodeterioration \& Biodegradation 104: 231-237.

Bari, E.; Oladi, R.; Schmidt, O.; Clausen, C.A.; Ohno, K.; Nicholas, D.D.; Ghodskhah Daryaei, M.; Karim, M. 2015b. Influence of xylem ray integrity and degree of polymerization on bending strength of beech wood decayed by Pleurotus ostreatus and Trametes versicolor. International Biodeterioration \& Biodegradation 104: 299-306.

Bari, E.; Schmidt, O.; Oladi, R. 2015c. A histological investigation of Oriental beech wood decayed by Pleurotus ostreatus and Trametes versicolor. For Pathol 45: 349-357.

Bari, E.; Taghiyari, H.R.; Mohebby, B.; Clausen, C.A.; Schmidt, O.; Vaseghi, M.J. 2015d. Mechanical properties and chemical composition of beech wood exposed for 30 and 120 days to whiterot fungi. Holzforschung 69: 587-593.

Bari, E; Taghiyari, H.R.; Naji, H.R; Schmidt, O.; Ohno, M.K.; Clausen, C.A.; Bakar, E.S. 2016. Assessing the destructive behavior of two white-rot fungi on beech wood. International Biodeterioration \& Biodegradation114: 129-140.

Bari, E; Karim, M.; Oladi, R.; Tajick Ghanbary, MA.; Ghodskhah Daryaei, M.; Schmidt, O.; Benz, J.P.; Emaminasab, M. 2017. The white-rot fungus Pleurotus ostreatus causes simultaneous decay in Oak trees in vivo. For Pathol 47:e12338.

Bellamy, L.J. 1975. The Infrared Spectra of Complex Molecules. Chapman and Hall, London: 299p. 1010.

Blanchette, R.A. 1995. Degradation of the lignocellulose complex in wood. Can J Bot 73(S1):999-

Bouslimi, B.; Koubaa, A.; Bergeron, Y. 2014. Effects of biodegradation by brown-rot decay on selected wood properties in eastern white cedar (Thuja occidentalis L.). International Biodeterioration \& Biodegradation 87: 87-98.

Bravery, A.F. 1978. Screening techniques for potential wood preservative Chemicals. IRG/WP 2113.

Carrillo, F.; Colom, X.; Sunõl, J.J.; Saurina, J. 2004. Structural FTIR analysis and thermal characterisation of lyocell and viscose-type fibres. Eur Polym J 40: 2229-2234.

Colom, X.; Carrillo, F.; Nogues, F.; Garriga, O. 2003. Structural analysis of photodegraded wood by means of FTIR spectroscopy. Polym Degrad Stabil 80: 543-549.

Cowling, E.B. 1961. Comparative biochemistry of the decay of sweetgum sapwood by white-rot and brown-rot fungi. Technical Bulletin-1258. USDA Forest Service, Washington, DC.

Curling, S.F.; Clausen, C.A.; Winandy, J.E. 2002. Relationships between mechanical properties, weight loss, and chemical composition of wood during incipient brown-rot decay. Forest Product Journal 52: 34-39.

Davis, M.W. 1998. A rapid modified method for compositional carbohydrate analysis of lignocellulosics by high $\mathrm{pH}$ anion-exchange chromatography with pulsed amperometric detection (HPAEC/PAD). $J$ Wood Chem Technol 18(2): 235-252.

Ding, S.Y.; Himmel, M.E. 2008. Anatomy and ultrastructure of maize cell walls: an example of energy plants. In: Himmel, M.E., (Ed.), Biomass recalcitrance. Deconstruction of the plant cell wall for bioenergy. Blackwell, London, pp: 38-60.

Eaton, RA.; Hale MDC. 1993. Wood: decay, pests and protection. Chapman and Hall: London. 
EN 113. 1997. Wood Preservatives-determination of the Toxic Values against Wood Destroying Basidiomycetes Cultured on Agar Medium.

Eriksson, K.E.L.; Blanchette, R.A.; Ander, P. 1990. Microbial and enzymatic degradation of wood and wood components. Springer: Berlin.

Fackler, K.; Stevanic, J.S.; Ters, T.; Hinterstoisser, B.; Schwanninger, M.; Salmen, L. 2011. FT-IR imaging microscopy to localise and characterize simultaneous and selective white-rot decay within spruce wood cells. Holzforschung 65: 411-420.

Gartner, H.; Schweingruber, F.H. 2013. Microscopic preparation techniques for plant stem analysis. Kessel, Remagen.

Hale, MDC.; Eaton, RA. 1985a. Oscillatory growth of fungal hyphae in wood cell walls. Trans Br Mycol Soc 84: 277-288.

Hale, MDC.; Eaton, RA. 1985b. The ultrastructure of soft-rot fungi. II. Cavity forming hyphae in wood cell walls. Mycologia 77: 594-605.

Hartig, R. 1878. Die Zersetzungserscheinungen des Holzes der Nadelholzbaume und der Eiche in forstlicher, botanischer und chemischer Richtung. Springer: New York.

Hatakka A.; Hammel K.E. 2010. Fungal Biodegradation of Lignocelluloses. In: HOFRICHTER $M(E d)$ The Mycota. $2^{\text {nd }}$ ed. Springer: Berlin, Heidelberg, New York, pp: 319-340.

Hervé, V.; Mothe, F.; Freyburger, C.; Gelhaye, E.; Frey-Klett, P. 2014. Density mapping of decaying wood using X-ray computed tomography. International Biodeterioration \& Biodegradation 86: 358-363.

Hinterstoisser, B.; Salmen, L. 2000. Application of dynamic 2D FTIR to cellulose. Vib Spectros 22: 111-118.

Karim, M.; Ghodskhah Daryaei, M.; Torkaman, J.; Oladi, R.; Tajick Ghanbary, M.A.; Bari, E. 2016. In vivo investigation of chemical alteration in Oak wood decayed by Pleurotus ostreatus. International Biodeterioration \& Biodegradation 108: 127-132.

Karim, M.; Ghodskhah Daryaei, M.; Torkaman, J.; Oladi, R.; Tajick Ghanbary, M.A.; Bari, E.; Yilgor, N. 2017. Natural decomposition of hornbeam wood decayed by the white rot fungus Trametes versicolor. An Acad Bras Cien 89(4):2647-2655.

Kartal, N.S; Terzi, E.; Yılmaz, H.; Goodell, B. 2015. Bioremediation and decay of wood treated with ACQ, micronized ACQ, nano-CuO and CCA wood preservatives. International Biodeterioration \& Biodegradation 99: 95-101.

Kirk, T.K.; Koning, J.W.; Burgess, R.R.; Akhtar, M.; Blanchette, R.A.; Cameron, D.C.; Cullen, D.; Kersten, P.J.; Lightfoot, E.N.; Myers, G.C.; Sachs, I.; Sykes, M.; Beth Wall, M. 1993. Biopulping. A glimpse of the future? USDA Forest Serv. Res. Paper FPL-RP-523.

Kim, J.S.; Gao, J.; Daniel, G. 2015. Cytochemical and immunocytochemical characterization of wood decayed by the white rot fungus Pycnoporus sanguineus I. preferential lignin degradation prior to hemicelluloses in Norway spruce wood. International Biodeterioration \& Biodegradation 105: 30-40.

Klemm, D.; Schmauder, H.P.; Heinze, T. 2004. Cellulose. In: Steinbüchel, A. (Ed.), Biopolymers Volume 6, Polysaccharides II: Polysaccharides from Eukaryotes Münster-Germany: Wiley-VCH.

Kondo, T. 1997. The assignment of IR absorption bands due to free hydroxyl groups in cellulose. 
Cellulose 4: 281-292.

Koshijima, T.; Watanabe, T. 2003. Association between lignin and carbohydrates in wood and other plant tissues. Springer: Berlin Heidelberg New York.

Kubicek, C.P. 2013. Fungi and lignocellulosic biomass. John Wiley \& Sons, Inc: Chichester.

Liers, C.; Ullrich, R.; Steffen, K.T.; Hatakka, A.; Hofrichter, M. 2006. Mineralization of ${ }^{14} \mathrm{C}$-labelled synthetic lignin and extracellular enzyme activities of the wood-colonizing ascomycetes Xylaria hypoxylon and Xylaria polymorpha. Appl Microbiol Biotechnol 69: 573-579. 258.

Liese, W. 1970. Ultrastructural aspects of woody tissue disintegration. Ann Rev Phytopath 8: 231-

Mann, J.; Marrinan, H.J. 1956. The reaction between cellulose and heavy water. Part 3.-A quantitative study by infra-red spectroscopy. Transactions of the Faraday Society 52:492-497.

Martinez, A.T; Camarero, S.; Gutiérrez, A.; Bochini, P.; Galleti, G.C .2001. Studies on wheat lignin degradation by Pleurotus species using analytical pyrolysis. Journal of Analytical and Applied Pyrolysis 58-59: 401-411.

Martinez, A.T.; Speranza, M.; Ruiz-Dueñas, F.J.; Ferreira, P.; Camarero, S.; Guillén, F.; Martínez, M.J.; Gutiérrez, A.; del Río, J.C. 2005. Biodegradation of lignocellulosics: microbial, chemical, and enzymatic aspects of the fungal attack of lignin. Intern Microbiol 8: 195-204.

Mohebby, B. 2003. Biological attack of acetylated wood. Ph.D. thesis, Göttingen University, Germany.

Mohebby, B. 2005. Attenuated total reflection infrared spectroscopy of white-rot decayed beech wood. International Biodeterioration \& Biodegradation 55: 247-251.

Nagadesi, P.; Arya, A.; Albert, S. 2013. Delignification pattern of wood decay by white rot fungi in teak (Tectona grandis L. f.). J Indian Acad Wood Sci 10: 1-8.

O’Sullivan, A.C. 1997. Cellulose: the structure slowly unravels. Cellulose 4: 173-207.

Pandey, K.K; Pitman, A.J. 2003. FTIR studies of the changes in wood following decay by brownrot and white-rot fungi. International Biodeterioration \& Biodegradation 52: 151-160.

Pandey, K.K.; Theagarajan, K.S. 1997. Analysis of wood surfaces by diffuse reflectance (DRIFT) and photoacoustic (PAS) Fourier transform infrared spectroscopic techniques. Holz als Rohund Werkstoff 55: 383-390.

Popescu, C.M.; Popescu, M.C.; Singurel, G.; Vastile, C.; Argyropoulos, D.; Willfor, S. 2007. Spectral characterization of eucalyptus wood. Appl Spectr 61: 1168-1177.

Rayner, A.D.M.; Boddy, L. 1988. Fungal decomposition of wood: its biology and ecology. Wiley: Chichester.

Schmidt, O. 2006. Wood and Tree Fungi: Biology, Damage, Protection, and Use. Springer: Berlin, Heidelberg.

Schmidt, O.; Bahmani, M.; Koch, G.; Potsch, T.; Brandt, K. 2016. Study of the fungal decay of oil palm wood using TEM and UV techniques. International Biodeterioration \& Biodegradation 111: 37-44.

Schmidt, O.; Gaiser, O.; Dujesiefken, D. 2012. Molecular identification of decay fungi in the 
wood of urban trees. Eur J Forest Res 131: 885-891.

Schubert, M.; Volkmer, T.; Lehringer, C.; Schwarze, F.W.M.R. 2011. Resistance of bioincised wood treated with wood preservatives to blue-stain and wood-decay fungi. International Biodeterioration \& Biodegradation 65: 108-115.

Schwanninger, M.; Rodrigues, J.C.; Pereira, H.; Hinterstoisser, B. 2004. Effects of short-time vibratory ball milling on the shape of FT-IR spectra of wood and cellulose. Vib Spectros 36: 23-40.

Schwarze, F.W.M.R.; Engels, J.; Matthek, C. 2004. Fungal strategies of wood decay in trees. $2^{\text {nd }}$ ed. Springer: Berlin, Heidelberg, New York.

Schwarze, F.W.M.R. 2007. Wood decay under the microscope. Fun Biol Rev 21: 133-170.

Sjöström, E. 1993. Wood Chemistry, Fundamentals and Applications. Academic, San Diego.

Stokland, J.N.; Siitonen, J.; Jonsson, B.G. 2012. Biodiversity in dead wood. Cambridge University Press, New York.

Sugiyama, J.; Persson, J.; Chanzy, H. 1991. Combined infrared and electron diffraction study of the polymorphism of native celluloses. Macromolecules 24: 2461-2466.

Sunardi, Tanabe J.; Ishiguri, F.; Ohshima, J.; Iizuka, K.; Yokota, S. 2016. Changes in lignocellulolytic enzyme activity during the degradation of Picea jezoensis wood by the white-rot fungus Porodaedalea pini. Int Biodeter Biodegr 110: 108-112.

TAPPI standard. 1998. Standard methods for acid-insoluble lignin in wood and pulp. T 222. om98.

TAPPI standard. 1992. Standard methods for Carbohydrate composition of extractive-free wood and wood pulp by gas-liquid chromatography. T249 $\mathrm{cm}-85$.

TAPPI standard. 1997. Cellulose in wood. T17 wd-97.

Tashiro, K.; Kobayashi, M. 1991. Theoretical evaluation of three-dimensional elastic constants of native and regenerated celluloses: role of hydrogen bonds. Polymer 32(8): 1516-1526.

Timell, T.E. 1967. Recent progress in the chemistry of wood hemicelluloses. Wood Sci Technol 1: $45-70$

Wilcox, W.W. 1973. Degradation in relation to wood structure. In: Nicholas, D.D., (Ed.) Wood deterioration and its preservation by preservative treatments. Syracuse University Press, Syracuse. pp. 107-148.

Woodward, S.; Boddy, L. 2008. Interactions between saprotrophic fungi. In: Boddy, L; Frankland, JC; Van West, P (Eds.) Ecology of saprotrophic Basidiomycetes. Academic Press, Elsevier.

Yang, B.; Wyman, C.E. 2004. Effect of xylan and lignin removal by batch and flow through pretreatment on the enzymatic digestibility of corn stover cellulose. Biotechnol Bioeng 86:88-95. 